\title{
SUMBER DAYA PERIKANAN TANGKAP DI WADUK KOTO PANJANG, RIAU
}

\author{
Andri Warsa, Adriani Sri Nastiti Krismono, dan Amula Nurfiarini \\ Peneliti pada Loka Riset Pemacuan Stok Ikan, Jatiluhur-Purwakarta \\ Teregristrasi I tanggal: 28 Pebruari 2007; Diterima setelah perbaikan tanggal: 14 Mei 2007; \\ Disetujui terbit tanggal: 15 Pebruari 2008
}

\begin{abstract}
ABSTRAK
Waduk Koto Panjang dengan luas 12.400 ha sebagian besar terletak di Kecamatan XIII Koto Kampar, Kabupaten Kampar Propinsi Riau, dan sebagian kecil termasuk di Propinsi Sumatera Barat. Waduk ini merupakan waduk multi fungsi antara lain sebagai pembangkit listrik tenaga air, irigasi, wisata, dan perikanan. Di bidang perikanan, Waduk Koto Panjang merupakan sumber pendapatan bagi sekitar 400 nelayan. Hasil tangkapan didominasi oleh ikan paweh (Osteochilus haseltii) $(35,2 \%)$, motan (Thynnichthy polylepis) (28,2\%), dan siban (Cyclocheilicthys apogon) (14,8\%). Beberapa jenis ikan ekonomis penting antara lain ikan baung (Hemibragus nemurus), tapah (Wallago sp.), belida (Chitala lopis), tabingalan (Puntioplites bulu), toman (Channa micropeltes), gurame (Osphronemus goramy) dengan potensi produksi 170.4 ton. Tingkat pendapatan nelayan berkisar Rp.116.966 sampai Rp.126.700 per trip di mana tingkat pendapatan ini dipengaruhi oleh jumlah alat tangkap yang dimiliki oleh nelayan.
\end{abstract}

\section{KATAKUNCl: perikanan tangkap, Waduk Koto Panjang, ikan ekonomis penting}

\section{PENDAHULUAN}

Perikanan tangkap memberikan sumber protein bagi lebih dari 1 milyar orang di dunia dan menjadi sumber penghidupan bagi 200 juta orang. Konsumsi per kapita diharapkan meningkat dari $16 \mathrm{~kg}$ menjadi 19 sampai $21 \mathrm{~kg}$ pada tahun 2030 (Rudolf WU, 2005). Stok ikan di berbagai tipe perairan umum seperti danau, waduk, sungai, dan lagoon telah dieksploitasi untuk tujuan perikanan. Produksi total perikanan tangkap perairan umum daratan dunia pada tahun 2001 mencapai 8,7 juta ton dan sedikit menurun dari produksi tahun 2000 (8,8 juta ton). Perikanan tangkap perairan umum daratan menyumbang sekitar $6,7 \%$ dari produksi global, sedangkan perikanan laut dan budi daya masing-masing menyumbang 59,8 dan 34,1\% (Marashi, 1996).

Masalah yang berhubungan dengan pengelolaan perikanan perairan umum daratan sangat kompleks. Stok ikan dipengaruhi oleh beberapa faktor antara lain polusi (penyuburan, limbah beracun, dan hujan asam), pembendungan (river engineering, impoundments, land drainage, dan flood alleviation), hilangnya habitat yang disebabkan oleh reklamasi tanah dan pembuangan tanaman air, penggundulan hutan, introduksi spesies non aktif dan over fishing.

Waduk Koto Panjang dengan luas 12.400 ha sebagian besar terletak di Kecamatan XIII Koto Kampar, Kabupaten Kampar, Propinsi Riau. Waduk ini merupakan waduk multi fungsi antara lain sebagai pembangkit listrik tenaga air, Irigasi, wisata, dan perikanan. Waduk Koto Panjang mendapat pasokan air dari Sungai Kampar Kanan, Kapau, Tiwi, Takus, Gulamo, Mahat, Osang, Cunding, Arau Kecil, dan
Arau Besar. Di waduk ini pernah dilakukan penebaran jenis ikan tawes (Puntius javanicus), mas (Cyprinus carpio), baung (Macrones nemurus), dan patin (Pangasius sp.). Waduk Koto Panjang merupakan waduk dengan tingkat kesuburan menengah (mesotropik) (Nastiti et al., 2006). Waduk Koto Panjang merupakan lahan untuk mendapatkan sumber mata pencaharian bagi 400 nelayan.

Lahan sekitar waduk telah banyak yang berubah fungsi menjadi lahan perkebunan. Hal ini dapat menyebabkan penurunan kualitas perairan karena ketika musim penghujan akan terjadi erosi sehingga banyak partikel tanah yang masuk ke dalam badan air. Pada awal penggenangan di dalam badan air banyak terdapat tumbuhan tingkat tinggi yang telah mati (Gambar 1) yang memberikan masukkan bahan organik yang berakibat pada penurunan konsentrasi oksigen terlarut.

\section{Komposisi Jenis Ikan}

Estimasi potensi perikanan di Waduk Koto Panjang berdasarkan klorofil-a berkisar 81,4 sampai $258,3 \mathrm{~kg}$ per ha per tahun (Nastiti et al., 2006). Jenis ikan yang ditemukan di Waduk Koto Panjang berkisar 24 jenis (Tabel 1 ).

Penangkapan ikan tapah (Wallago sp.) oleh nelayan dilakukan dengan menggunakan jaring dan pancing dengan berbagai ukuran (Anonimus, 2003). Ikan hasil tangkapan di Waduk Koto Panjang di dominasi oleh ikan paweh (Osteochilus haseltii) (35,2\%), motan (Thynnichthys polylepis) (28,2\%), dan siban (Cyclocheilicthys apogon) (14,8\%). 


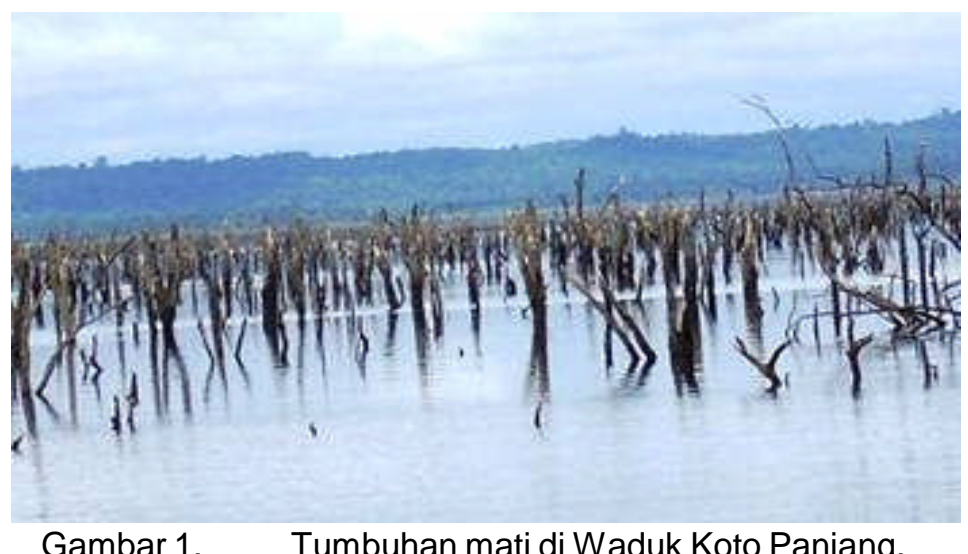

Tabel 1. Beberapa jenis ikan dan komposisi hasil tangkapan

\begin{tabular}{llc}
\hline \multicolumn{1}{c}{ Nama daerah } & \multicolumn{1}{c}{ Nama latin } & Komposisi hasil tangkapan (\%) \\
\hline Singkeh & \multicolumn{1}{c}{ Pristolepis grooti } & 0,6 \\
Katung & Cyclocheilicthys apogon & 1,8 \\
Siban & Thyninichthy polylepis & 14,9 \\
Motan & Hampala macrolepidota & 28,2 \\
Barau & Hemibragus nemurus & 1,1 \\
Baung & Barbodes schwanefeldii & 2,5 \\
Kapiek & Osphronemus goramy & 3,9 \\
Gurame & Osteochilus haseltii & 0,4 \\
Paweh & & 35,2 \\
Timah-timah & Puntioplites sp. & 0,05 \\
Toakang & Puntioplites bulu & 2,3 \\
Tabingalan & & 0,05 \\
Palau & Hemibragus nigriceps & 0,3 \\
Senggiring/tunggik & & 0,8 \\
Sipaku & Xenentodon canciloides & 0,05 \\
Julung-julung & Channa bankanensis & 1,9 \\
Nulo/Bujuk & Oreochromis niloticus & 0,1 \\
Nila & Channa Striata & 0,4 \\
Gabus & Mastacoleombus sp. & 1,1 \\
Tilan & Labeobarbus festivus & 0,25 \\
Mali & Oxygater anomalura & 2,6 \\
Ping-ping & Pristolepis fasciata & 0,3 \\
Beterung & Chitala hipselonotus & 0,5 \\
Belida & Rasbora argyrotaenia & 0,1 \\
Pantau & Wallago sp. & 0,6 \\
Tapah & & 0,05 \\
\hline Sur: & &
\end{tabular}

Sumber: Nastiti et al. (2006)

Keterangan: - belum teridentifikasi

Beberapa jenis ikan merupakan ikan ekonomis penting seperti disajikan pada Gambar 2 dan Tabel 2.

Ketersediaan pakan alami akan menunjang keberadaan populasi ikan di suatu badan air. Kelimpahan plankton di Waduk Koto Panjang berkisar $84.504-1.137 .786$ ind./L. Jenis fitoplankton didominasi oleh kelas Chlorophyceae, Bacillariophyceae, Cyanophyceae, dan Dynophyceae. Kelimpahan plankton yang demikian menyokong kehidupan ikan herbivora yang mana pakan utamanya adalah fitoplankton sehingga beberapa jenis ikan antara lain ikan paweh dan motan merupakan ikan yang dominan tertangkap di Waduk Koto Panjang, 

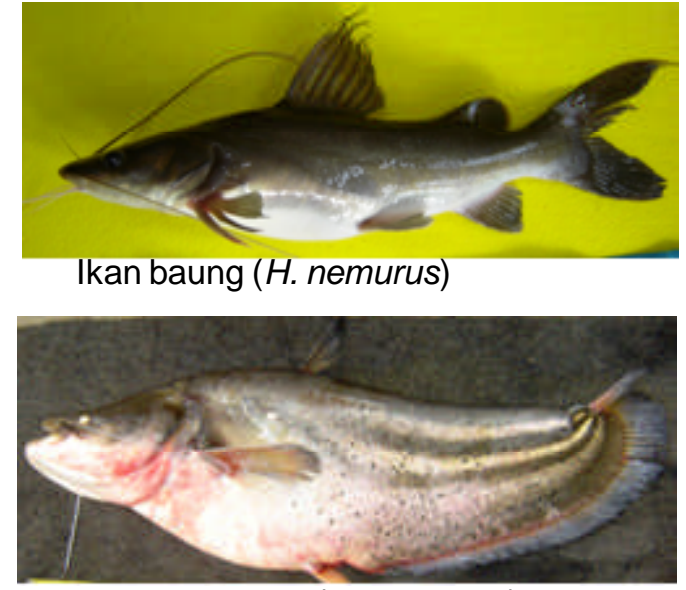

Ikan tapah (Wallago sp.)

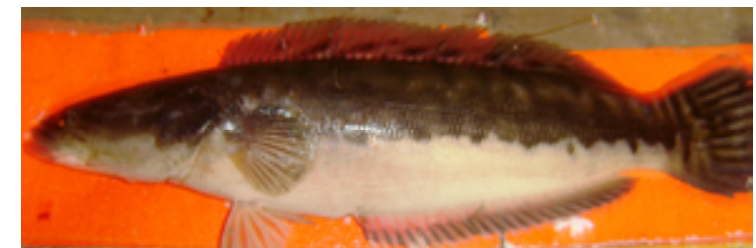

ikan toman (C. micropeltes)

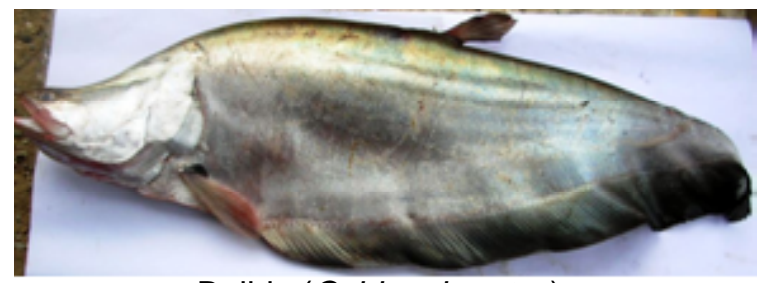

Belida (C. hipselonotus)

Gambar 2. Beberapa jenis ikan ekonimis penting di Waduk Koto Panjang.

Tabel 2. Ikan ekonomis penting dan harga jual

\begin{tabular}{lccc}
\hline \multicolumn{1}{c}{ Jenis ikan } & \multicolumn{3}{c}{ Harga (Rp./kg) } \\
\cline { 2 - 4 } & Nelayan & Pengumpul & Konsumen akhir \\
\hline Baung (Henibragus nemurus) & 20.000 & 25.000 & 40.000 \\
Tapah (Wallago sp.) & 35.000 & 40.000 & 60.000 \\
Belida (Chitala hipselonotus) & 28.000 & 35.000 & 50.000 \\
Tabingalan (Puntioplites bulu) & 22.000 & 30.000 & 40.000 \\
Toman (Channa micropeltes) & 10.000 & 14.000 & 15.000 \\
Gurame(Osphronemus goramy) & 10.000 & 14.000 & 17.000 \\
\hline
\end{tabular}

Riau. Bentos di Waduk Koto Panjang, yaitu Insekta, Lamellibranchiata, dan Gastropoda mempunyai kelimpahan 484 sampai 1.936 ind. per $\mathrm{m}^{2}$. Jenis ikan pemakan bentos di Waduk Koto Panjang antara lain adalah ikan tilan (Mastacoleombus sp.) dan baung (Henibragus nemurus).

Berdasarkan analisis pola kebiasaan pakan (food habits), beberapa jenis ikan yang terdapat di waduk ini dapat dibagi menjadi 4 kelompok, yaitu:

1. Herbivora adalah jenis ikan spesialis pemakan fitoplankton yaitu ikan paweh, toakang (Puntioplites sp.), nila (Oreochromis niloticus), dan motan, sedangkan spesialis pemakan tumbuhan adalah gurame (Osphronemus goramy).

2. Omnivora pemakan zooplankton dan detritus yaitu ikan tabingalan (Puntioplites bulu) dan spesialis pemakan serangga dan detritus yaitu wajang.

3. Karnivora yaitu tilan, senggiring (Hemibragus nigriceps), barau (Hampala macrolepidota), katung (Pristolepis grooti), kapiek (Barbodes schwanefeldii), ping-ping (Oxygater anomalura), julung-julung (Xenentodon canciloides), dan siban (Cyclocheilicthys apogon).
4. Predator yaitu ikan baung (Henibragus nemurus), gabus (Channa Striata), toman (Channa micropeltes), dan serepang.

\section{Kegiatan Perikanan Tangkap}

Jumlah nelayan di Waduk Koto Panjang adalah 400 RTP, terdiri atas 275 RTP nelayan penuh dan 125 RTP nelayan sambilan. Jumlah kepemilikan alat tangkap pukat dengan ukuran mata jaring 1,5; 3,0 sampai 12,0 inci adalah 20 buah per RTP, pancing no.2, 3, sampai 5 berkisar 80 sampai 200 buah per RTP dan trap sekitar 10 sampai 20 buah per RTP. Nelayan di Waduk Koto Panjang tersebut belum terorganisir dan belum terbentuk kelompok. Tingkat pendapatan nelayan berkisar Rp.116.966 sampai 126.700. Tingkat pendapatan ini dipengaruhi oleh jumlah alat tangkap yang dimiliki oleh nelayan. Daerah penangkapan meliputi seluruh waduk yang terpusat di perairan Batu Besurat, Muara Takus, Gunung Bungsu, dan Rantau Berangin (Nastiti et al., 2006).

Metode penangkapan adalah cara penggunaan alat untuk mendapatkan hasil tangkapan yang memadai, sedangkan alat tangkap merupakan sarana untuk mewujudkannya (Surur, 2004). Berdasarkan 


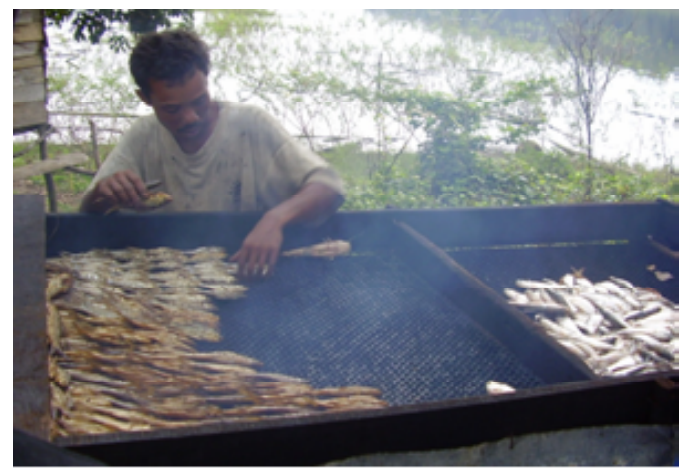

Gambar 3. Kegiatan pembuatan ikan asap.

Tabel3. Nilai tambah ikan salai ikan motan (T. polylepis) dan baung (H.nemurus)

\begin{tabular}{lcc}
\hline & Motan & Baung \\
\hline Nilai jual ikan salai per kg & 35.000 & 60.000 \\
Bahan baku ikan segar per $3 \mathrm{~kg}$ & 15.000 & 20.000 \\
Biaya produksi (Rp.) meliputi transport, bahan bakar, dan & 7.500 & 7.500 \\
tenaga kerja & & $\mathbf{4 2 . 5 0 0}$ \\
\hline Nilai tambah (Rp.) & $\mathbf{1 2 . 5 0 0}$ & $\mathbf{4}$ \\
\hline
\end{tabular}

alat tangkap yang digunakan, metode penangkapan di Waduk Koto Panjang dapat dikelompokkan ke dalam metode pasif.

Kegiatan lain yang banyak dilakukan oleh nelayan di Waduk Koto Panjang adalah penangkapan benih ikan gurame. Ukuran benih yang tertangkap berkisar 3 - 5 inci dengan harga jual Rp.1.000,-/ekor. Penangkapan dilakukan baik pada siang maupun malam hari dan puncaknya pada bulan Maret - Juni. Peralatan yang digunakan dalam penangkapan benih ikan gurame ini adalah pancing dengan hasil tangkapan 100 ekor/trip.

Pemanfaatan secara terus-menerus tanpa diimbangi dengan pengelolaan akan menurunkan potensi perairan atau perikanan. Pengelolaan perairan perlu dilakukan antara lain dengan pengaturan penangkapan, pengadaan suaka perikanan, dan pembentukan kelompok nelayan.

\section{Pengolahan Hasil Tangkapan}

Ikan hasil tangkapan nelayan di Waduk Koto Panjang dapat diolah menjadi ikan salai (ikan asap). Hal ini dilakukan guna meningkatkan harga jual hasil tangkapan. Beberapa jenis ikan yang sering diolah menjadi ikan salai adalah ikan motan, belida, tapah, gabus, dan baung yang sangat digemari oleh masyarakat. Ikan salai ikan motan diekspor ke Singapura dengan harga jual Rp.100.000,-/kg.
Pengolahan ikan salai oleh nelayan ini dilakukan secara berkelompok dan ikan segar sebagai bahan baku utama diperoleh baik dari tangkapan sendiri maupun membeli dari nelayan lainnya. Pengerjaan dilakukan secara tradisional dengan peralatan yang digunakan:

1. Tungku sederhana yang terbuat dari kayu dan kawat untuk meletakkan ikan.

2. Kayu bakar sebagai sumber panas.

Proses pembuatan ikan salai yaitu ikan dibersihkan dengan membuang isi perutnya. Setelah itu, ikan diletakkan di atas tungku pemanas selama 12 - 14 jam hingga kering dan berwarna kecoklatan (Gambar 3). Ikan segar yang telah diolah akan mengalami penyusutan bobot dari $1 \mathrm{~kg}$ ikan segar menjadi $300 \mathrm{~g}$ ikan salai. Usaha ini cukup menguntungkan bagi nelayan di Waduk Koto Panjang.

Setelah diolah menjadi ikan salai, ikan hasil tangkapan akan meningkat harga jualnya. Sebagai contoh, pembuatan $1 \mathrm{~kg}$ ikan salai membutuhkan bahan baku ikan motan dan baung segar masingmasing $3 \mathrm{~kg}$. Formulasi nilai tambah adalah:

$$
\mathrm{NT}=\mathrm{NJ}-(\mathrm{BB}+\mathrm{BP})
$$


di mana:

$\mathrm{NT}=$ nilai tambah

$\mathrm{NJ}=$ nilai jual

$\mathrm{BB}=$ bahan baku

$\mathrm{BP}=$ biaya produksi (Soekartawi, 1988)

Tabel 3 menunjukkan bahwa nilai tambah ikan motan adalah Rp.12.500,-/3 kg ikan segar (Rp.4.166,67/kg ikan segar) dan nilai tambah ikan baung adalah Rp.42.500,-/3 kg ikan segar atau Rp.14.166,67/kg ikan segar. Hal ini menunjukkan bahwa pengolahan ikan segar menjadi ikan salai dapat memberi keuntungan yang dapat meningkatkan pendapatan nelayan setempat. Di samping itu, penyalaian ikan dapat menampung ikan pada saat hasil tangkapan melimpah dan dapat menyimpan ikan dalam jangka waktu yang lama.

\section{KESIMPULAN}

1. Perikanan tangkap di Waduk Koto Panjang merupakan sumber mata pencaharian bagi nelayan.

2. Nelayan belum terorganisir, belum ada kelompok.

3. Belum ada pengelolaan sumber daya perikanan di Waduk Koto Panjang.

\section{SARAN}

Perlu dilakukan pengelolaan sumber daya perikanan berupa suaka, pembentukan organisasi nelayan, dan peraturan penggunaan alat tangkap yang didukung oleh data riset.

\section{PERSANTUNAN}

Kegiatan dari hasil riset rehabilitasi populasi ikan di Danau Teluk Jambi dan Waduk Koto Panjang, Riau, T.A. 2006, Loka Riset Pemacuan Stok Ikan, Jatiluhur.

\section{DAFTAR PUSTAKA}

Anonimus. 2003. Laporan pelaksanaan pemantauan rencana pengelolaan lingkungan dan rencana pemantauan lingkungan pembangkit listrik tenaga air Koto Panjang. Kerja sama Perusahaan Listrik Negara Sektor Pekanbaru. Pusat Penelitian Lingkungan Hidup Universitas Riau. Pekanbaru.

Marashi, S. H. 1996. The Role of FAO Regional Fishery Bodies in the Conservation and Management of Fisheries. FAO fisheries Circular No.916 FIPL/C 916. Rome. FAO.

Nastiti, S. N., H. Satria, D. W. H. Tjahjo, K. Purnomo, S. Nurdawati, A. Nurfiarini, A. Suryandari, A. Warsa, Y. Sugianti, S. E Purnamaningtyas, \& Mujianto. 2006. Rehabilitasi populasi ikan di Danau Teluk, Mahligai, Napalsisik (Jambi), dan Waduk Koto Panjang (Riau). Laporan Tahunan atau Akhir. Loka Riset Pemacuan Stok Ikan. Laporan Teknis. (tidak dipublikasi).

Rudolf, W. U. 2005. Sustainable capture fisheries. Training Workshop on Food Security 26-30 September 2005. UNITAR Hiroshima Office for Asia and the Pacific. Series on Sea and Human Security. Hiroshima. Japan.

Soekartawi. 1988. Ekonomi Produksi. LP3ES. Jakarta.

Surur, F. 2004. Alat dan Cara Penangkapan Ikan. Jilid I. Departemen Kelautan dan Perikanan. Jakarta. 